\section{A STUDY OF SERUM URIC ACID LEVELS IN TYPE 2 DIABETES MELLITUS CASES AND ITS COIMPARISON WITH THE SERUIM CREATININE LEVELS}

KEY WORDS: Diabetes mellitus, Fasting blood sugar, Serum uric acid, Serum creatinine.

\section{Dr. Shajahan}

\section{Dr.Koneru Sri} Lahari*

\section{Dr. P. Kiranmai}

$3^{\text {rd }}$ year MD Biochemistry Postgraduate, Osmania Medical College, Hyderabad,Telangana, India.

$3^{\text {rd }}$ Year MD Biochemistry Postgraduate, Osmania Medical College, Hyderabad, Telangana, India. * Corresponding Author

MD, Associate Professor, Department Of Biochemistry, Osmania Medical College, Hyderabad,Telangana,India.

BACKGROUND: Type 2 Diabetes Mellitus is a major non-communicable disease resulting from insulin resistance and is associated with cardiovascular, neurological and renal complications. Recent studies show association of hyperuricemia and Diabetes Mellitus. Uric acid increases oxidative stress that leads to vascular dysfunction and high intra glomerular pressure leading to renal complications. High serum creatinine is an indicator of renal compromise.

OBJECTIVES: To evaluate serum uric acid and serum creatinine levels in type 2 diabetes mellitus patients and to find association between them.

METHODOLOGY: The study was conducted in Osmania general hospital. Fifty cases of established Type 2 Diabetes Mellitus formed the study group and 50 normal healthy individuals formed the control group. Serum uric acid, Fasting Blood Glucose (FBS) and serum creatinine were estimated by colorimetric enzymatic methods on Beckman coulter AU5800. Mean values were compared in cases and controls using student t- test. Study group was further studied under 2 subgroups with serum Uric acid $<7 \mathrm{mg} / \mathrm{dl}$ and $\geq 7 \mathrm{mg} / \mathrm{dl}$. In these 2 subgroups the association of Serum uric acid with FBS and creatinine was analysed statistically.

RESULTS: Serum uric acid were found high in cases(7.63+/- 3.36)as compared to controls(4.48+/- 1.09) $\mathrm{p}$ value $<$ 0.001.Serum creatinine were also high in cases(1.59+/- 1.39 )as compared to controls ( $0.87+/-0.29) \mathrm{p}$ value $<0.005$. Study subgroup with serum uric acid $\geq 7 \mathrm{mg} / \mathrm{dl}$ was associated with high creatinine and high fasting blood sugar levels when compared to subgroup with serum uric acid $<7 \mathrm{mg} / \mathrm{dl}$.

CONCLUSION: Our study showed increased serum uric acid and serum creatinine levels in cases when compared to controls. There was significant association between high serum uric acid and high creatinine levels in cases. Therefore, it is important to measure serum uric acid and serum creatinine levels in diabetics for early detection of renal pathology.

\section{BACIKGROUND}

\section{INTRODUCTION:}

According to WHO, Diabetes Mellitus is defined as a metabolic disorder of multiple aetiology, characterised by chronic hyperglycaemia along with disturbances of carbohydrate, protein and fat metabolism resulting from defects in insulin secretion or insulin action or both(1). Diabetes mellitus is one of the major non-communicable diseases and is a leading public health problem with increasing incidence and long term complications such as diabetic nephropathy, diabetic neuropathy, diabetic retinopathy etc., which are mainly a consequence of macro and micro vascular damages of the target organs. The international federation of diabetes reported that adults suffering from diabetes all over the world are around 415 million and this estimation is likely to reach around 642 million by 2040(2). The worst affected age group is between 40-59 years (3). Risk factors contributing to diabetes mellitus include obesity, unsatisfactory diet, sedentary lifestyle and increasing urbanisation. The cause of clinical diabetes includes both absolute and relative deficiencies of insulin. Type 1 diabetes mellitus is due to insulin deficiency caused by autoimmune destruction of beta cells in the islets of pancreas (4). Type 2 diabetes mellitus is characterised by insulin resistance and impaired insulin receptors.

Uric acid is the end product of purine metabolism in humans. Uric acid production varies with the purine content of the diet, rate of purine biosynthesis, degradation and salvage pathway $(5,6)$. Hyperuricemia is defined by serum uric acid concentration greater than $7.0 \mathrm{mg} / \mathrm{dl}$ in men or greater than 6 $\mathrm{mg} / \mathrm{dl}$ in women. Many studies revealed that hyperuricemia is associated with CVD and premature deaths from MI and stroke $(7,8)$. Recent studies have demonstrated that serum uric acid levels are higher in subjects with pre-diabetes and early type 2 diabetes than in healthy controls(9). Current hypothesis states that oxidative stress is a common pathogenic factor leading to diabetes. Free radicals are generated during uric acid production, thus uric acid levels might indicate excessive oxidative stress. Hyperuricemia has also been added to the set of metabolic abnormalities associated with insulin resistance in metabolic syndrome (10, 11 , and 12).

Serum Creatinine is known to be raised with hyperglycaemia in diabetes, usually correlating with kidney damage severity. This study was designed to evaluate the levels of serum uric acid in type 2 diabetes mellitus patients and to compare with serum creatinine levels.

\section{MATERIALS AND METHODS:}

This is a case control study conducted in Osmania General Hospital in the month of September 2020. Both male and female subjects were included in the age group of 35-70 years. Prior consent was taken.

INCLUSION CRITERIA:(I) 50 patients who were diagnosed clinically and biochemically as Diabetes Mellitus based on $A D A$ guidelines attending out-patient department were enrolled for the study. (ii) 50 normal healthy individuals were included as controls in the study.

EXCLUSION CRITERIA: (a) pregnancy (b) patients with renal stones and renal failure (c) liver diseases (d) drugs affecting renal function and uric acid levels (e) any other systemic illness that may affect the renal function.

Study subjects had undergone clinical examination.

- $3 \mathrm{ml}$ of fasting venous blood was collected into grey vacutainer in both cases and controls and fasting blood sugar levels were measured by enzymatic method on Beckman coulter AU5800.

- $5 \mathrm{ml}$ of venous blood was collected into red vacutainer, serum was separated and serum uric acid and serum creatinine levels were measured by enzymatic methods on Beckman coulter Au5800. 


\section{STATISTICAL ANALYSIS:}

- From our data, the mean, percentage, standard deviation, chi-square test and multiple correlations were done by using SPSS-10.

- The $p$ value was used to compare the cases mean value with control mean value and the $p$ value of $<0.005$ was considered statistically significant.

\section{RESULTS:}

The study included 50 cases and 50 healthy controls. The study group was further studied under 2 sub-groups with serum uric acid $<7 \mathrm{mg} / \mathrm{dl}$ and $>/=7 \mathrm{mg} / \mathrm{dl}$.In these 2 subgroups the association of Serum uric acid with Fasting blood sugar levels between $125-200 \mathrm{mg} / \mathrm{dl}$ and $>200 \mathrm{mg} / \mathrm{dl}$ and serum creatinine levels $<1.3 \mathrm{mg} / \mathrm{dl}$ and $>/=1.3 \mathrm{mg} / \mathrm{dl}$ were analyzed statistically.There were 46 females and 54 males in our study.The mean for age in the cases and controls were $56.04+/-13.46$ and $53.83+/-10.64$ respectively (table no. 1 ).

\section{Table no. 1: Age distribution}

\begin{tabular}{|c|c|c|}
\hline & Cases & Controls \\
\hline No. of study subjects & 50 & 50 \\
\hline Age (years) mean +/-SD & $56.04+/-13.46$ & $53.82+/-10.64$ \\
\hline
\end{tabular}

The Fasting Blood Sugar(FBS) of the cases and controls had mean of $189.9+/-46.30$ and $97.4+/-15.50$ respectively.Majority of the cases (56\%) had FBS levels between $125-200 \mathrm{mg} / \mathrm{dl}$ while $44 \%$ of the cases had FBS levels of $>200 \mathrm{mg} /$ dl.Mean serum uric acid levels in cases and controls were $7.63+/-3.36$ and $4.48+/-1.09$ respectively.Mean serum creatinine levels in cases \& controls were $1.59+/-1.39$ and $0.87+/-0.29$ respectively.P value for all the parameters were considered statistically significant (table no.2).

Table no. 2: Comparison of study parameters in cases and controls

\begin{tabular}{|l|l|l|l|}
\hline parameters & $\begin{array}{l}\text { Cases mean } \\
\text { +/-SD }\end{array}$ & $\begin{array}{l}\text { Controls } \\
\text { mean +/-SD }\end{array}$ & $\begin{array}{l}\text { P } \\
\text { value }\end{array}$ \\
\hline $\begin{array}{l}\text { Fasting blood } \\
\text { sugar(mg/dl) }\end{array}$ & $189.9+/-46.30$ & $97.4+/-15.50$ & $<0.001$ \\
\hline $\begin{array}{l}\text { Serum uric } \\
\text { acid(mg/dl) }\end{array}$ & $7.63+/-3.36$ & $4.48+/-1.09$ & $<0.001$ \\
\hline $\begin{array}{l}\text { Serum } \\
\text { creatinine(mg/dl) }\end{array}$ & $1.59+/-1.39$ & $0.87+/-0.29$ & $<0.005$ \\
\hline
\end{tabular}

Out of 25 of the study subjects with FBS levels between 125$200 \mathrm{mg} / \mathrm{dl}, 18 \mathrm{had}$ serum uric acid levels of $<7 \mathrm{mg} / \mathrm{dl}$ and $7 \mathrm{had}$ uric acid levels of $\geq 7 \mathrm{mg} / \mathrm{dl}$. Out of 25 of the study subjects with FBS levels of $>200 \mathrm{mg} / \mathrm{dl}, 8$ had serum uric acid levels of $<7 \mathrm{mg} / \mathrm{dl}$ and $17 \mathrm{had} \geq 7 \mathrm{mg} / \mathrm{dl}$. There was significant association seen between FBS levels and serum uric acid levels in the study subjects $(p<0.001)$ (table no.3, fig. 1).

Table no. 3: Association between serum uric acid and fasting blood sugar (Fig. 1.)

\begin{tabular}{|l|l|l|l|}
\hline \multirow{2}{*}{$\begin{array}{l}\text { Serum uric } \\
\text { acid(mg/dl) }\end{array}$} & \multicolumn{2}{|l|}{ Fasting blood sugar(mg/dl) } & Total \\
\cline { 2 - 4 } & $\mathbf{1 2 5 - 2 0 0}$ & $\mathbf{2 0 0}$ & \\
\hline $\mathbf{~ 7 ~}$ & 18 & 8 & 26 \\
\hline $\mathbf{7}$ 7 & 7 & 17 & 24 \\
\hline Total & 25 & 25 & 50 \\
\hline
\end{tabular}

Fig. 1. Association between serum uric acid and fasting blood sugar

= Fasting blood sugar(mg/dl) $\geq 200 \quad$ " Fasting blood sugar(mg/dl) 125-200

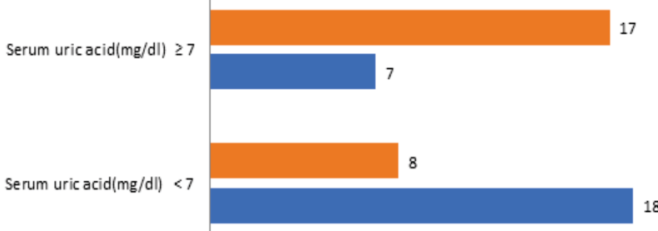

Out of 27 of the study subjects with serum creatinine levels of $<1.3 \mathrm{mg} / \mathrm{dl}, 24 \mathrm{had}$ serum uric acid levels of $<7 \mathrm{mg} / \mathrm{dl}$ and 3 had $\geq 7 \mathrm{mg} / \mathrm{dl}$.Out of 23 of the study subjects with serum creatinine levels of $\geq 1.3 \mathrm{mg} / \mathrm{dl}$, 8 had serum uric acid levels of $<7 \mathrm{mg} / \mathrm{dl}$ and $15 \mathrm{had} \geq 7 \mathrm{mg} /$ dl. There was significant association seen between the serum uric acid and serum creatinine levels in the cases $(p<0.001)$. We observed that with elevated serum creatinine levels, there was also increase in serum uric acid levels (table no. 4 , fig. 2).

Table no. 4: Association between serum uric acid and serum creatinine (Fig. 2.)

\begin{tabular}{|l|l|l|l|}
\hline \multirow{2}{*}{ Serum uric acid(mg/dl) } & \multicolumn{2}{|l|}{ Serum creatinine(mg/dl) } & Total \\
\cline { 2 - 4 } & $<\mathbf{1 . 3}$ & $\mathbf{2 1 . 3}$ & \\
\hline $\mathbf{2 7}$ & 24 & 8 & 32 \\
\hline $\mathbf{7}$ & 3 & 15 & 18 \\
\hline Total & 27 & 23 & 50 \\
\hline
\end{tabular}

Fig. 2. Association between serum uric acid and serum creatinine

- Serum creatinine $(\mathrm{mg} / \mathrm{d} \mid)<1.3 \quad$ m $\operatorname{Serum}$ creatinine $(\mathrm{mg} / \mathrm{d})>=1.3$
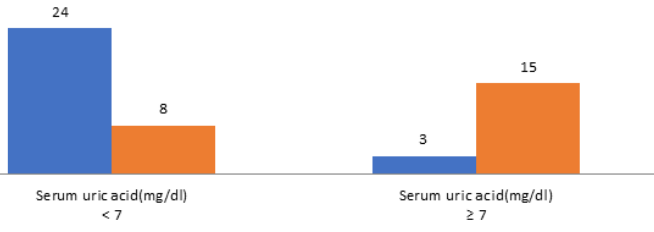

\section{DISCUSSION:}

Diabetes mellitus is a chronic disorder that is associated with cardiovascular, renal and various types of microangiopathies including metabolic syndrome. Hyperuricemia has been also added to the set of metabolic abnormalities associated with insulin resistance or hyperinsulinemia in metabolic syndrome. Oxidative stress is a common pathogenic factor leading to diabetes. Free radicals are generated during uric acid production, thus uric acid levels might indicate excessive oxidative stress.

In our study we measured serum uric acid levels in diabetes mellitus patients and compared it with the normal healthy individuals. The mean uric acid level was significantly high in the study group $(7.63+/-3.36)$ when compared to the control group $(4.48+/-1.09)$ and the $\mathrm{p}$ value is found statistically significant.

The mean serum creatinine level was also high in the study group $(1.59+/-1.39)$ when compared to the control group $(0.87+/-0.29)$ and the $p$ value is found statistically significant. There was significant association seen between serum uric acid and serum creatinine levels in cases $(p<0.001)$.

Uric acid is the ultimate product of purine metabolism in the human body (13). Serum uric acid has been suggested to be associated with risk of type 2 diabetes mellitus. Fructose is the main component of added sugar which causes mitochondrial oxidative stress $(14,15)$ and inhibits AMPK (16) and the subsequent intracellular ATP depletion (17) and nucleotide turnover leads to a significant increase in serum uric acid (18). Excessive uric acid leads to an increase in reactive oxygen species (ROS) production, which results in inflammation and dysfunction in the vessels (19). This oxidative stress can affect the expression of insulin gene causing decrease in insulin secretion (20).

Creatinine is the breakdown product of creatinine phosphate is released from skeletal muscle at a steady rate. It is filtered by the glomerulus, and a small amount is also secreted into the glomerular filtrate by the proximal tubule (21) and therefore it is helpful for tracking the progression of diabetic kidney disease. 
Bombelli et al $(22,23)$ conducted a study among 3200 northern Italian residents between the ages of 25 and 74 and found that increased uric acid resulted in an increased risk of impaired fasting glucose (IFG), and people with higher median uric acid levels may also develop metabolic syndrome and diabetes. Similar studies were conducted by Yan et al (24), Kuwata (25), Du et al. (26) and found hyperuricemia associated with diabetes and its complications.

Biologically, uric acid plays an important role in worsening of insulin resistance by inhibiting the bioavailability of nitric oxide, which is essential for insulin-stimulated glucose uptake. Hyperinsulinemia as a consequence of insulin resistance causes an increase in serum uric acid concentration by both reducing renal uric acid secretion and accumulating substrates for uric acid production. Therefore it remains controversial whether serum uric acid is independently associated with the development of type 2 diabetes mellitus.

As many studies supports the present study, analysis of serum uric acid and serum creatinine in type 2 diabetic subjects may be used as an associated biochemical parameter to follow the course of the disease and to assess any complications are going on as seen in advanced diabetic cases.

\section{CONCLUSION:}

Our study showed increased serum uric acid and serum creatinine levels in cases when compared to controls. It is also seen that there was significant association between serum uric acid and creatinine levels in cases. Therefore it is important to evaluate serum uric acid and serum creatinine levels routinely in diabetes mellitus patients for screening of further complications.

\section{REFERENCES:}

1. Liese AD, Hense HW, Lo wel H, Do ring A, Tietze M, KeilU.Association of serum uric acid with all-cause and cardiovasculardisease mortality and incident myocardial infarction in the MONICA-Augsburg cohort: World Health Organization MonitoringTrends and Determinants in Cardiovascular Diseases. Epidemiology 1999; 10:391-397.

2. Akhtar SN, Dhillon P. Prevalence of diagnosed diabetes and associated risk factors: Evidence from the large-scale surveys in India. Journal of Social Health andDiabetes $2017 ; 1 ; 5: 28$.

3. Kanellis J, Kang DH. Uric acid as a mediator of endothelial dysfunction, inflammation, and vascular disease. SeminNephrol2005;25:39-42.

4. Chen JH, Chuang SY, Chen HJ, Yeh WT, Pan WH. Serum uric acid level as an independent risk factor for all-cause, cardiovascular and ischemic stroke mortality: a Chinese cohort study. Arthritis Rheum 2009;61:225-232.

5. Masseoud D, Rott K, Liu-Bryan R, Agudelo C. Overview of hyperuricaemia and gout. Curr Pharm Des 2005;11(32):41174124.

6. Rafey MA, Lipkowitz MS, Leal-Pinto E, Abramson RG. Uric acid transport.Current opinion in nephrology and hypertension.2003;12(5):511-516.

7. Marchesini GR, Meulenberg E, Haasnoot W, Mizuguchi M, Irth H. Biosensor recognition of thyroid-disrupting chemicals usingtransport proteins. Anal Chem2006;78(4):1107-1114.

8. Cameron JS, Simmonds HA. 6.4 Uric acid and the kidney. Oxford Textbook of Clinical Nephrology 2005;2:1059.

9. Alberti KG, Zimmet P, Shaw J. Metabolic syndrome-anew world-wide definition. A consensus statement from the international diabetes federation. Diabetic medicine 2006;23:469-80.

10. Rich SS. Mapping genes in diabetes: genetic epidemiological perspective. Diabetes 1990;39:1315-1319.

11. Cook JT, Shields DC, Page RC, et al. Segregation analysis of NIDDM in Caucasian families, Diabetologia 1994;37:1231-1240.

12. Perley MJ, Kipnis DM. Plasma insulin responses to oral and intravenous glucose: studies in normal and diabeticsubjects.J Clin Invest 1967;46:1954-1962.

13. Y. Lytvyn, B. A. Perkins, and D. Z. I. Cherney, "Uric acid as a biomarker and a therapeutic target in diabetes," Canadian Journal of Diabetes, vol. 39, no. 3, pp. 239-246,2015.

14. M. A. Lanaspa, C. Cicerchi, G. Garcia et al., "Counteracting roles of AMP deaminase and AMP kinase in the development of fatty liver," PLOS One, vol. 7 , no. 11, Article ID e48801,2012.

15. M. A. Lanaspa, L. G. Sanchez-Lozada, Y.-J. Choi et al., "Uric acid induces hepatic steatosis by generation of mitochondrial oxidative stress," Journal of Biological Chemistry, vol.287,no.48,pp.40732-40744,2012.

16. C. Cicerchi, N. Li, J. Kratzer et al., "Uric acid-dependent inhibition of AMP kinase induces hepatic glucose production in diabetes and starvation: evolutionary implications of the uricase loss in hominids," The FASEB Journal, vol.28,no. 8,pp.3339-3350,2014

17. T. Ishimoto, M. A. Lanaspa, M. T. Le et al., "Opposing effects of fructokinase C
and A isoforms on fructose-induced metabolic syndrome in mice," Proceedings of the National Academy of Sciences, vol. 109, no. 11, pp. 4320-4325, 2012

18. R. J. Johnson, T.Nakagawa, L. G. Sanchez-Lozada et al., "Sugar, uric acid, and the etiology of diabetes and obesity," Diabetes, vol.62, no. 10,pp.3307-3315, 2013.
19. M. A. Yu, L. G. Sanchez-Lozada, R. J. Johnson et al., "Oxidative stress with an activation of the renin-angiotensin system in human vascular endothelial cells as a novel mechanism of uric acid-induced endothelial dysfunction," Journal of Hypertension, vol. 28, no. 6, pp. 1234-1242,2010.

20. T. Matsuoka, Y. Kajimoto, H. Watada et al., "Glycation-dependent, reactive oxygen species-mediated suppression of the insulin gene promoter activity in HIT cells,"Journal of Clinical Investigation, vol.99, no. 1, pp. 144-150, 1997.

21. Schrier RW, Gottschalk CW, Disease of the Kidney, (5th Ed.). Boston, little,Brown, 1993;2153-89.

22. M.Bombelli,F. Quarti-Trevano, M.Tadic et al., "Uric acid and risk of new-onset metabolic syndrome, impaired fasting glucose and diabetes mellitus in a general Italian population," Journal of Hypertension, vol. 36, no. 7, pp. 1492-1498,2018.

23. T. Anothaisintawee, D. Lertrattananon, S. Thamakaison et al., "Direct and indirect effects of serum uric acid on blood sugar levels in patients with prediabetes: a mediation analysis," Journal of Diabetes Research, vol. 2017, Article ID 683067 1,6 pages, 2017.

24. D. D. Yan, J.Wang, F. Jiang et al., "A causal relationshipbetween uric acid and diabetic macrovascular disease in Chinese type 2 diabetes patients: a Mendelian randomization analysis," International Journal of Cardiology, vol. 214,pp. 194-199,2016

25. H. Kuwata, S. Okamura, Y. Hayashino et al., "Serum uric acid levels are associated with increased risk of newly developed diabeticretinopathy among Japanese male patients with type 2 diabetes: a prospective cohort study (diabetes distress and care registry at Tenri [DDCRT 13])," Diabetes/Metabolism Research and Reviews,vol.33,no.7,p.e2905,2017.

26. L.Du,J.Ma, and X. Zhang, "Higher serum uric acid may contribute to cerebral infarction in patients with type 2 diabetes mellitus: a meta-analysis,"Journal of Molecular Neuroscience, vol.61,no. 1, pp. 25-31,2017. 